flint in the chalky series attracted much attention, being both vertical and horizontal in its mode of occurrence. Prof. Morris made some valuable observations on silicification in limestones, and Mr. Phillips collected specimens with a view to microscopic examination. A rather fine crustacean was found at the base of the chalky series, and a very large specimen in fint of Avicula modiolavis? The Cyrena-beds, as usual, yielded the bulk of the fossils. Mr. Lilly, the lessee of the quarries, was very obliging in describing the varieties of the lower building stones, and ultimately some of the party accompanied him into the excarations on the west side.

Chicksgrove Mill Quarry was next visited. The junction of the Purbeck and Portlend Beds occurs here under totally different circumstances, which the Director and Mr. Andrews took care to point out. Only a portion of the members went as far as Wockley quarry, and finally the party reassembled at Tisbury station to leave by the 4.32 p.m. train, going eastward.

\title{
EXCURSION TO CHARLTON, BLACKHEATH AND LEWISHAM.
}

APRIL 30TH, 1881.

Director:-J. Logan Loblay, Esq., F.G.S.

\section{(Report by The DIRECTOR,)}

As on previous visits of the Association to Charlton, the party at once proceeded to the great Chalk and Ballast pit to see the fine section showing the junction of the Secondaries and Tertiaries. This well-known section has been so fully described in the "Proceedings of the Geologists' Association," that it is only necessary here to state that the formations seen-the Chalk with flints, the Thanet Sands, and the Woolwich Beds-were described by the Director, who then led the way to the almost equally famous section at Hanging Wood Hill, displaying the Woolwich shell-beds. These at once attracted attention. The Upper and Lower Cyrena beds are very well developed and the shells, in good condition, may be obtained in abundance. The

* Proc. Geol. Assoc., Vol, iii., p. 205, Vol. iv., p. 528 and p. 557. 
species are Cyrena cuneiformis, C. deperdita, and C. cordata. In addition to the Cyrenas the shell-beds yield amongst other species the gasteropods Melania inquinata, and Cerithium funatum in considerable abundance, but the "Ostrea bed" of the Ballast pit section thins out at this place. Overlying the shell-beds we find the "Plant bed," noticed by Mr. H. J. Johnston Lavis, F.G.S., in 1876, containing Dicotyledonous leaves and seed-vessels, but it is not nearly so well developed here as at Lewisham and Bromley.

Ascending to the summit of the hill a very fine view over the Lower Thames Valley was obtained, and the river being filled with a high tide at the time the scene was particularly striking. The hilly and undulating ground on the south side of the Woolwich road contrasted with the quite flat marshes between the road and the river formed of alluvial deposits overlying the beds thrown down by the great fault running along the course of the road. The old river bank was thus well seen, and it was pointed out that while the top of the Chalk was twenty-feet above the level of the road on its south side it was upwards of a hundred feet below that level on the other side.

A pretty Tertiary valley was now crossed, and on the summit of the opposite side the village of Old Charlton was reached, standing on the verge of the plateau of Oldharen or Blackheath Beds which extends westward to the west end of Blackheath. The old manor house, built by Inigo Jones, looks over another of the indentations which fimbriate the platean along its northern side. A temporary road section near Blackheath afforded an opportunity of noting the character of the Oldhaven Beds of this part of Kent, which consist of well rounded blue-black pebbles, imbedded in sand.

On reaching Blackheath, the party assembled around the shaft sunk for the purpose of investigating the cause of the subsidences which have occasioned so much anxiety and interest amongst the inhabitants of the neighbourhood. The first of these sinkings occurred after an unusually heary fall of rain on April 12th, 1878; but this attracted little attention compared with that caused by two others which took place in November last. Almost circular openings in the Heath were formed of a diameter of seven or eight feet, widening bell-shape fashion below, and having a depth of nearly twenty feet. Arrangements had been courteously made to afford every facility to the Geologists by Mr. H. W. Jackson, F.G.S., the Hon. Secretary of the Lewisham and Blackheath 
Scientific Association, who are prosecuting the investigation, and awaiting the party was the Astronomer Royal, Sir George Biddle Aiery. The Director having read an account of the subsidences and of the steps which had been taken to ascertain their canse from the Engineer, of February 4th last, Mr. Jackson stated the present position of the exploring operations, which consisted of the sinking of a shaft at one of the subsidences, and the careful examination of the material removed. A depth of 35 feet had been reached, and at this point water flowed into the excavation abundantly, and brought with it a large amount of sand. This had greatly impeded the progress of the work as almost constant pumping was required to enable the excavation to be continued. The pebble-beds not having been penetrated, the Woolwich Beds and the Thanet Sands would still lie between them and the Chalk. He had had the mound of fallen material carefully compared with the undisturbed surrounding beds, and had found a seam of red sandy clay exactly corresponding with such a seam in these beds, showing that the portion of the surface which had fallen in consisted of previously undisturbed material, and not of an artificial stopping of some old excavation. The conclusion he was led to by the observations so far made was that the sinkings were due to hydrogeological causes. He considered that the constant passing of water through the sand-surrounded pebbles and its outlow above the Woolwich Clays would carry away so much of the finer material as would cause a subsidence of the beds in places at first below and eventually at the surface.

On the other hand Mr. V. Holmes, F.G.S., who knows the locality well, was of the opinion that the sinkings were caused by ancient artificial excarations, similar to the "Grime's Graves," met with at various places in the western part of Kent.

After the thanks of the party had been given to Mr. Jackson, another of the sinkings was visited. This was found to be in an undisturbed condition, which gave it an interest of its own. A descent was made into the opening and the fallen material examined, when no difference could be perceived between it and the unfallen beds around, both consisting of the typical pebbles and sand.

The party now proceeded to Lewisham, passing, near the west end of the Heath, a good exposure of the Pebble-beds. At Loam Pit Hill, the Geologists again assembled, when this most interest- 
ing and valuable section was explained. This section, like that at Charlton, has been fully described in these pages.* It shows the Chalk with Thanet Sands above considerably thinner than at Charlton, the Woolwich Beds better developed, the Blackheath pebbles reduced to less than a foot in thickness, and the Basementbed of the London Clay with about, in one place, 20 feet of the London Clay itself.

The party returned to London from Lewisham Junction.

\section{ORDINARY MEETING.}

MAX 6TH, 1881.

W. H. Hudleston, Esq., M.A., F.G.S., President, in the Chair.

The Donations to the Library were announced as usual, and the donors thanked.

The following were elected Members of the Association:Henry M. Platnauer, Esq., John D. Butler, Esq., T. Hay Wilson, Esq., and William Smith, Esq.

The following paper was read :-

On Conifera. By J. S. Gardner, Esq., F.G.S.

\section{EXCURSION TO CROYDON, SHIRLEY, AND ADDINGTON.}

Saturday, May 7 th, 1881.

Directors :-John Flower, Esq., M.A., F.Z.S., J. Logan

Lobley, Esq., F.G.S., and H. M. KlaAssen, Esq.

The Members of the Association having been joined, at East Croydon Station, by a number of the Members of the Croydon Microscopical and Natural History Club, the party proceeded eastward along the Upper Addiscombe Road, passing over the extreme western edge of the Oldhaven Beds and a small outlier of London Clay, extending northward from Park Hill. The sands of the

* See Proc. Geol. Assoc. Vol, iv., p. 528. 